South African Journal of Geomatics, Vol. 4, No. 2, June 2015

\title{
An assessment of coastal vulnerability for the South African coast
}

\author{
Chiedza Musekiwa ${ }^{1}$, Hayley C. Cawthra ${ }^{1}$, Maxime Unterner ${ }^{2}$, F. Wilhelm van Zyl ${ }^{1}$
}

${ }^{1}$ Council for Geoscience, Bellville, 7535, Cape Town, South Africa, cmusekiwa@geoscience.org.za

${ }^{2}$ Ecole des Mines de Nantes, France

DOI: $\underline{\text { http://dx.doi.org/10.4314/sajg.v4i2.5 }}$

\section{Abstract}

Coastal vulnerability is the degree to which a coastal system is susceptible to, or unable to cope with, adverse effects of climate change. One of the most widely used methods in assessing risk and vulnerability of coastlines on a regional scale includes the calculation of vulnerability indices and presenting these results on a vulnerability map. These maps can assist coastal managers, planners, landowners and stakeholders identify regions of greater risk to coastal hazards and ultimately better inform mitigation and development strategies.

This paper discusses the creation of a coastal vulnerability map for South Africa. The criteria used included elevation to chart datum, beach width, tidal range, wave height, geology, geomorphology, anthropogenic activities, distance to $20 \mathrm{~m}$ isobaths and relative sea level change. The values of these parameters were divided into classes and the various classes ranked on a scale of 1 (very low vulnerability) to 5 (very high vulnerability) using examples from literature and expert knowledge. The layers were combined using the spatial overlay (map algebra) technique to create the final map. The results highlight the most vulnerable areas along the coastlines as the areas surrounding the City of Cape Town (the west coast) and the regions close to East London and Port St. Johns on the east coast. This can be mainly attributed to the type of geology and the anthropogenic activities in these areas.

\section{Introduction}

Potential accelerated sea-level rise (referred to as sea-level rise) is a globally recognised hazard facing coastal regions. Sea-level rise is of great economic and ecological significance, considering the intensive human activity along the coastal zone and the impact of sea-level rise includes increases in the coastal processes of inundation and wave erosion (Bryan et al., 2001). The necessity of assessment of the vulnerability of coastal areas to sea-level rise has been recognised by the Intergovernmental Panel on Climate Change (IPCC, 2007). 
Coastal vulnerability assessment must incorporate the complex interactions of physical environmental factors at the coast which affect these coastal processes. Although the need for coastal vulnerability monitoring in South Africa has been recognised by various researchers (Mukheibir and Ziervogel, 2007; Roberts, 2010), these methods and ongoing results have to date only been published for the city of Durban (Palmer et al., 2011) and in a more regional sense in considering sandy beaches along the coast (Harris et al., 2011). These initiatives have mainly concentrated on sections of the coast and a regional map of coastal vulnerability for South Africa is not available. Such a map is essential as it shows broad patterns and can be the first pass to highlight hot spots before more detailed site specific studies can be conducted (Bryan et al., 2001).

There are various methods available for assessing coastal vulnerability including index-based methods, indicator-based approaches, GIS-based decision support systems and dynamic computer models (Ramieri et al., 2011). Index-based approaches express coastal vulnerability by a unitless index (value) based on the aggregation of various criteria. Indicator-based approaches express the vulnerability by a set of independent variables/indicators that characterise key coastal issues and in some cases these are scored with a value representing low, medium and high levels of concern for coastal vulnerability and these can be combined into one final indicator. GIS-based decision support systems (for example DESYCO) and computer models (InVEST) are more complex models that include more variables and equations and assess the complex interrelations between the variables, enabling the automation of the assessment of coastal vulnerability and also the simulation of the effects of future changes in the various parameters on overall vulnerability. Examples and advantages of the different approaches are discussed in detail in Ramieri et al., 2011. The indexbased method was used in this study because it is simple, is suitable for regional scale analysis and the required datasets are available.

\section{Methodology}

The methodology adopted in this study commenced with a synthesis of existing literature on coastal vulnerability both from South Africa and from international studies. This was followed by communication with experts to determine the final parameters applicable to South Africa. Table 1 presents the parameters and criteria of vulnerability that were used. A vulnerability classification that ranges from 1 (very low) to 5 (very high) has been adopted based on examples from literature (USGS, 2001; Sharp et al., 2010 and Palmer et al., 2011). 
Table 1. The coastal erosion parameters and vulnerability classes used in this study

\begin{tabular}{|c|c|c|c|c|c|}
\hline Vulnerability & Very low & Low & Moderate & High & Very high \\
\hline $\begin{array}{l}\text { Elevation to chart } \\
\text { Datum (m) }\end{array}$ & $>30$ & $>20$ to $\leq 30$ & $>10$ to $\leq 20$ & $>5$ to $\leq 10$ & $\leq 5$ \\
\hline Beach width (m) & $>150$ & $>100$ to $\leq 150$ & $>50$ to $\leq 100$ & $>20$ to $\leq 50$ & $\leq 20$ \\
\hline Tidal range (m) & $<1.0$ & $\geq 1.0$ to $<2.0$ & $\geq 2.0$ to $\leq 4.0$ & $>4.0$ to $\leq 6.0$ & $>6.0$ \\
\hline $\begin{array}{l}\text { Maximum wave } \\
\text { height (m) }\end{array}$ & $<3.0$ & $\geq 3.0$ to $<5.0$ & $\geq 5.0$ to $<6.0$ & $\geq 6.0$ to $<6.9$ & $\geq 6.9$ \\
\hline Geology & $\begin{array}{l}\text { Magmatic } \\
\text { rocks }\end{array}$ & $\begin{array}{l}\text { Metamorphic } \\
\text { rocks }\end{array}$ & $\begin{array}{l}\text { Sedimentary } \\
\text { rocks }\end{array}$ & $\begin{array}{l}\text { Unconsolidated } \\
\text { coarse sediments }\end{array}$ & $\begin{array}{l}\text { Unconsolidated } \\
\text { fine sediments }\end{array}$ \\
\hline $\begin{array}{l}\text { Anthropogenic } \\
\text { activities }\end{array}$ & $\begin{array}{c}\text { Shoreline } \\
\text { stabilisation } \\
\text { intervention }\end{array}$ & $\begin{array}{l}\text { Intervention } \\
\text { without } \\
\text { sediment } \\
\text { source } \\
\text { reduction }\end{array}$ & $\begin{array}{l}\text { Intervention } \\
\text { with sediment } \\
\text { source } \\
\text { reduction, } \\
\text { breakwater }\end{array}$ & $\begin{array}{l}\text { Without } \\
\text { intervention or } \\
\text { sediment source } \\
\text { reduction, } \\
\text { dams }\end{array}$ & $\begin{array}{l}\text { Without } \\
\text { intervention, but } \\
\text { with sediment } \\
\text { source reductions }\end{array}$ \\
\hline $\begin{array}{l}\text { Distance to } 20 \mathrm{~m} \\
\text { isobaths }(\mathrm{km})\end{array}$ & $>4$ & $>2$ to $<4$ & $>1$ to $<2$ & $>0.5$ to $<1$ & $<0.5$ \\
\hline $\begin{array}{l}\text { Relative sea-level } \\
\text { change (mm/year) }\end{array}$ & $<1.8$ & $>1.8$ to $<2.5$ & $>2.5$ to $<2.95$ & $>2.95$ to $<3.16$ & $>3.16$ \\
\hline $\begin{array}{l}\text { Mean wave height } \\
\text { (m) }\end{array}$ & $<0.55$ & $>0.55$ to $<0.85$ & $>0.85$ to $<1.05$ & $>1.05$ to $<1.25$ & $>1.25$ \\
\hline $\begin{array}{c}\text { Beach } \\
\text { geomorphology }\end{array}$ & $\begin{array}{l}\text { Boulder } \\
\text { beach }\end{array}$ & $\begin{array}{l}\text { Dissipative } \\
\text { beach }\end{array}$ & $\begin{array}{c}\text { Dissipative } \\
\text { intermediate } \\
\text { beach }\end{array}$ & Intermediate beach & Reflective beach \\
\hline
\end{tabular}

The following sections discuss the parameters used, their significance for coastal vulnerability, the classes for each parameter and the ranking applied. Points were created along the coastline where there was a change in coastline direction, with the spacing between points typically varying from 30 to $100 \mathrm{~m}$, and vulnerability values for all parameters were assigned to the points.

\subsection{Elevation to chart datum}

In terms of the effect of elevation on coastal vulnerability, the lower the relief of the coastal slope, the higher the susceptibility of the coast to flooding and inundation (Davies, 2012). The 90m shuttle radar topography mission (SRTM) elevation data was used (Figure 1). A vulnerability index was given to each pixel according to its assigned height (Table 1). Each point on the coastline was assigned the same vulnerability index as the pixel to which it intersected. Figure 1 shows the elevation classes used in the study. 


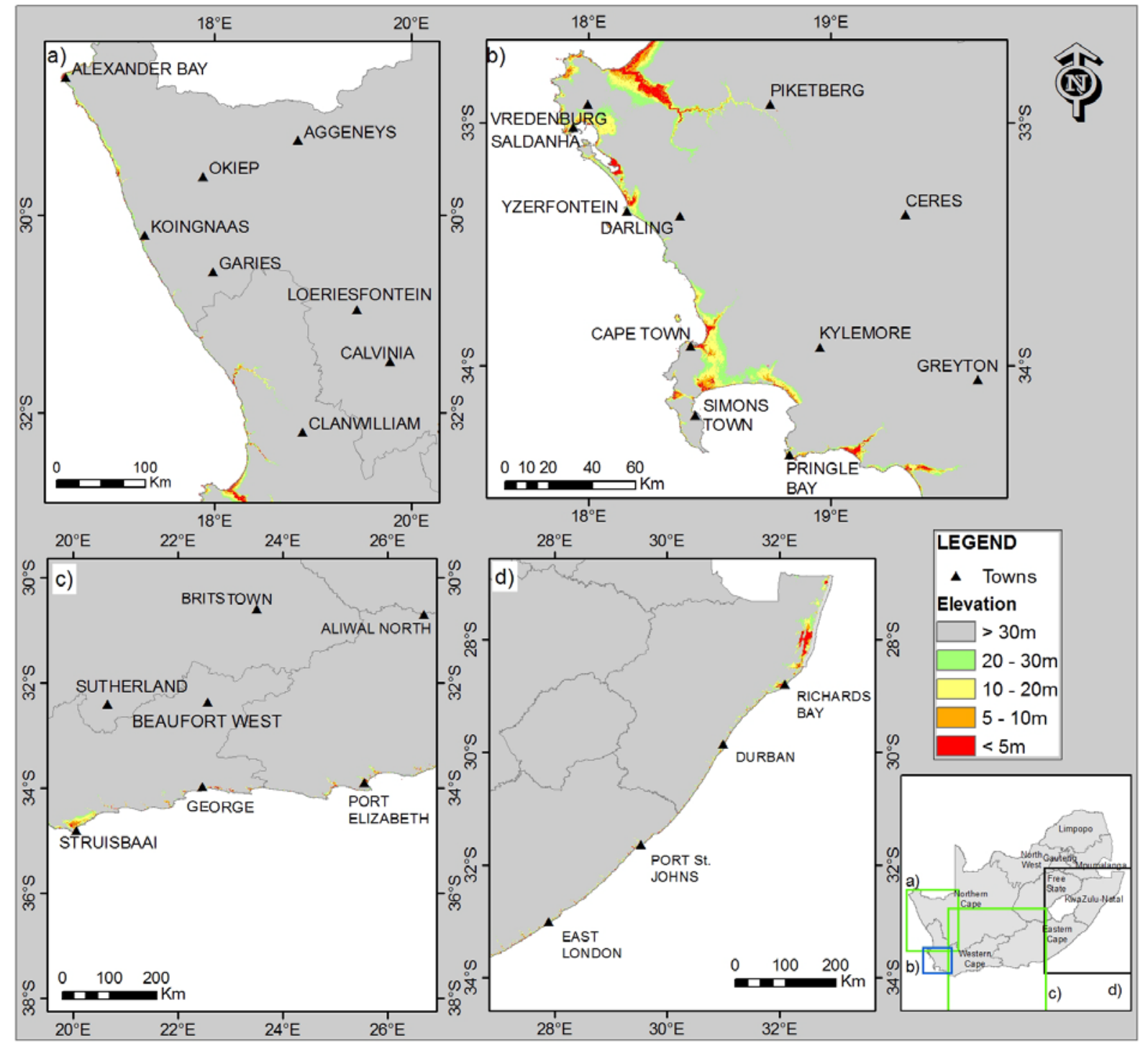

Figure 1. Elevation classes based on the 90m SRTM dataset

\subsection{Beach width}

Beach width affects coastal vulnerability by acting as a buffer, dissipating wave energy: the wider the beach, the greater the capacity of the beach to dissipate wave energy and reduce the impacts of extreme weather events. Areas with lower beach widths are invariably steeper and less able to dissipate energy (Davies, 2012). This parameter only considered the areas identified as sandy beaches. The vector based input data used to extract information on the nature of the coast (rock, beach, shore mixed), is based on the work published by Harris et al., 2011.

Only beaches longer than $1 \mathrm{~km}$ were considered, with the exception of beaches adjacent to infrastructure were beaches with lengths as low as $500 \mathrm{~m}$ were included. Beach perpendicular transects were digitised in Google Earth, showing the width of the sandy areas to the base of backbeach dunes / vegetated areas with a minimum of three lines for each sandy beach (Figure 2). 
The lengths of the digitised transects were calculated and they were used as a value for the beach width. A vulnerability class was assigned to each beach according to its average width (Table 1). Each vector point of the coastline was assigned the same vulnerability index as the beach it is located on.

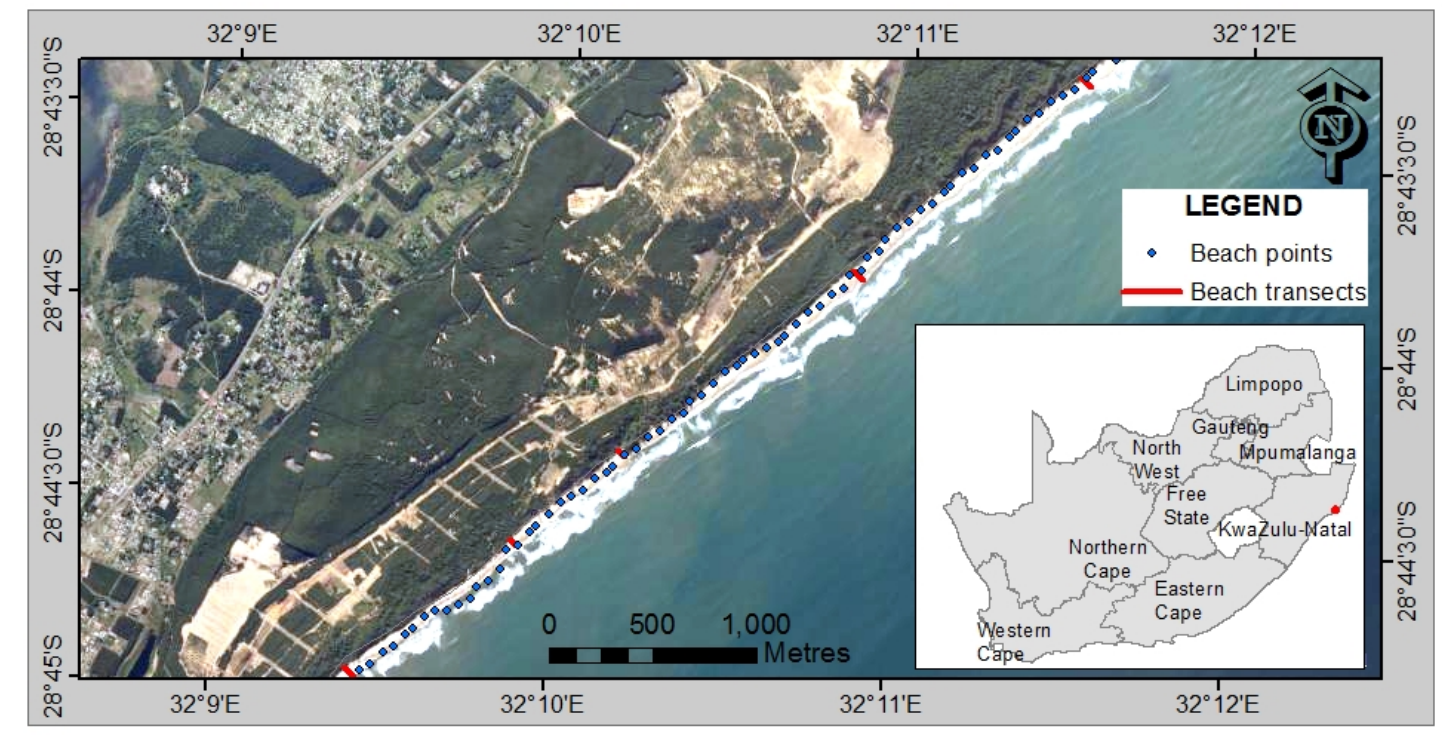

Figure 2. Beach width determination utilising measurements made on beach width transects

\subsection{Tidal range}

A large tidal range determines the spatial extent of the coast that is acted upon by waves. Areas with large tidal waves have wide, near zero relief in the intertidal zones and are susceptible to permanent inundation following sea-level rise. They are susceptible to episodic flooding associated with storm surges, particularly if they coincide with high tides (Doukakis, 2005). An average tidal range of $1.8 \mathrm{~m}$ was applied for the entire South African coastline, which is classified as microtidal. The value was based on data published by Davies (1980) and Cooper (2001). Each vector point on the coastline was assigned a vulnerability index of 2 (low risk).

\subsection{Maximum and mean wave height}

Waves and longshore currents actively transform the shoreline by shoreline material transport. This variable is an indicator of the amount of beach materials that may be moved offshore or permanently removed from the coastal sediment system (Doukakis, 2005). Wave heights were determined using a historical dataset available from the Windguru website (Windguru, 2011). 
This comprehensive dataset provides access to the wave height data at different stations (Table 2) with measurements either every 3 or 6 hours over a number of years. Where data are absent; this is represented with an ' $x$ ' in Table 2 at these stations.

Table 2. The largest wave heights for every station from the Windguru website from 2005-2010

\begin{tabular}{|c|c|c|c|c|c|c|c|}
\hline Year & 2005 & 2006 & 2007 & 2008 & 2009 & 2010 & \\
\hline Stations & & & & & & & $\begin{array}{c}\text { Average maximum } \\
\text { wave height }\end{array}$ \\
\hline Sodwana Bay & $\mathrm{x}$ & $\mathrm{x}$ & $\mathrm{x}$ & $\mathrm{x}$ & 4.9 & 5 & 5 \\
\hline Durban & 4.8 & 4.8 & 7.3 & 4.3 & 5.4 & 4.6 & 5.2 \\
\hline Margate & $\mathrm{x}$ & 5.7 & 7.7 & 5 & 6.5 & 5.8 & 6.1 \\
\hline East London & $\mathrm{x}$ & 6 & 6.5 & 6.6 & 7.4 & 6.6 & 6.6 \\
\hline Port Alfred & $\mathrm{x}$ & 5.8 & 7.1 & 6.5 & 7.2 & 6.3 & 6.6 \\
\hline Port Elizabeth & $\mathrm{x}$ & 5 & 5.5 & 6 & 6.5 & 5.7 & 5.7 \\
\hline Buffels Bay & $\mathrm{x}$ & $\mathrm{x}$ & $\mathrm{x}$ & $\mathrm{x}$ & 9.7 & 8.5 & 9.1 \\
\hline Richards Bay & $\mathrm{x}$ & $\mathrm{x}$ & $\mathrm{x}$ & 9.3 & 10.4 & 9.3 & 9.7 \\
\hline Mossel Bay & $\mathrm{x}$ & 6.8 & 8.1 & 8.9 & 9.5 & 8.2 & 8.3 \\
\hline Witsand & $\mathrm{x}$ & $\mathrm{x}$ & & 8.8 & 9.1 & 7.7 & 8.5 \\
\hline Hermanus & $\mathrm{x}$ & $\mathrm{x}$ & 8 & 9.9 & 9.7 & 8.1 & 8.9 \\
\hline Glencairn & $\mathrm{x}$ & $\mathrm{x}$ & $\mathrm{x}$ & $\mathrm{x}$ & $\mathrm{x}$ & 8.3 & 8.3 \\
\hline Cape Point & $\mathrm{x}$ & $\mathrm{x}$ & $\mathrm{x}$ & 10.4 & 10 & 8.4 & 9.6 \\
\hline Kommetjie & $\mathrm{X}$ & $\mathrm{X}$ & $\mathrm{x}$ & 10.4 & 9.9 & 8.3 & 9.5 \\
\hline Cape Town & 10.1 & 7.7 & 8.3 & 10.5 & 9.9 & 8.3 & 9.1 \\
\hline Yzerfrontein & $\mathrm{x}$ & $\mathrm{x}$ & $\mathrm{x}$ & 9.8 & 9.1 & 7.4 & 8.8 \\
\hline Eland's Bay & $\mathrm{x}$ & $\mathrm{x}$ & $\mathrm{x}$ & $\mathrm{x}$ & $\mathrm{x}$ & 6.8 & 6.8 \\
\hline Jacobs Bay & $\mathrm{x}$ & $\mathrm{x}$ & $\mathrm{x}$ & $\mathrm{x}$ & $\mathrm{x}$ & 6.7 & 6.7 \\
\hline Langebaan & 9 & 7 & 7.9 & 9.7 & 8.9 & 7 & 8.3 \\
\hline Knysna & $\mathrm{x}$ & 7.2 & 8.7 & 9.2 & 9.7 & 8.5 & 8.7 \\
\hline Elandsbaai & $\mathrm{x}$ & $\mathrm{X}$ & $\mathrm{x}$ & $\mathrm{X}$ & 6.8 & 6.9 & 6.9 \\
\hline Jeffrey’s Bay & $\mathrm{x}$ & 7.3 & 9.4 & 9.5 & 10.4 & 9.3 & 9.2 \\
\hline
\end{tabular}

A buffer of $10 \mathrm{~km}$ was created around the height stations. Each point along the coastline within the buffer zones was assigned the same vulnerability risk class as the station around which the buffer was generated. A point along the coastline between two buffers received a value that is the average of the two nearest buffered wave stations.

\subsection{Geology}

The nature and exposure of the local geology are important factors in determining the response to erosion, and therefore the susceptibility of the coastline to erosion. This depends on the hardness (and degree of lithification), composition, texture, structure and alteration levels of the adjacent bedrock and associated regolith.

The 1:250 000 scale Council for Geoscience geology lying within the $1 \mathrm{~km}$ buffer of the coast was used for this parameter (Figure 3). Geological polygons were assigned a vulnerability class based on the five broad categories defined in Table 1. Each point on the coastline was assigned the same risk class index as the geology polygon on which it was located. 


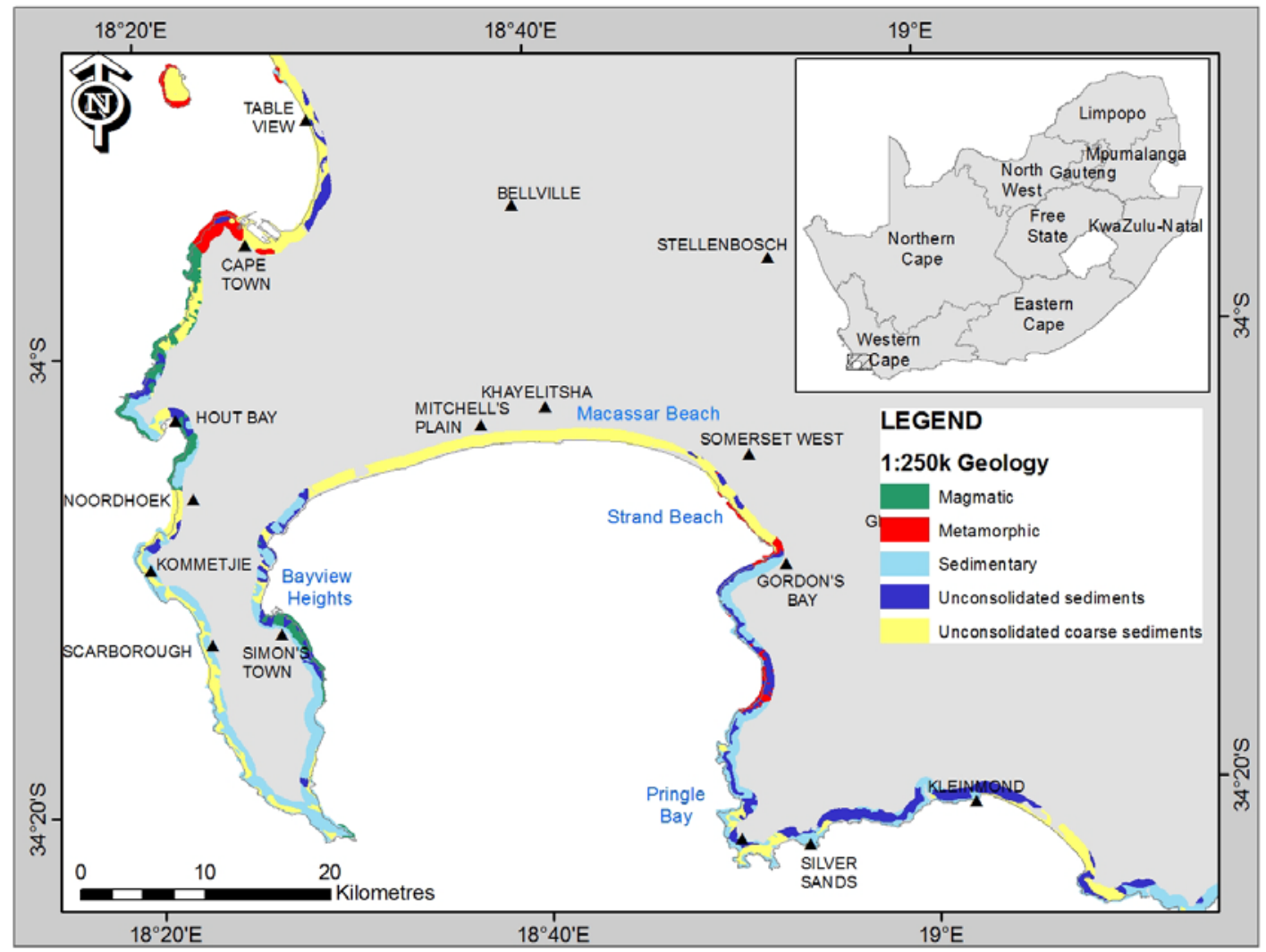

Figure 3. The geology along the Western Cape coastline

\subsection{Beach geomorphology}

Beach geomorphology is one of the factors dominating the existing coastal energy equilibrium conditions and determines the response to erosion associated with the erosivity risk of a coastal area. Beaches having silt-sized geological materials have a much higher erosivity risk than beaches made of boulders (Doukakis, 2005). Beach types were differentiated into boulder beaches, dissipative beaches, dissipative intermediate beaches, intermediate beaches and reflective beaches. This was carried out in accordance with the classification criteria defined by Harris et al. (2011). Each shoreline type was assigned a vulnerability index as shown in the Table 1; and each point on the coastline was assigned the same vulnerability index as the geomorphology of the surface it intersected.

\subsection{Anthropogenic activities}

The classification of land use incorporates infrastructure including ports and harbour breakwaters, as well as dams. The concentration of population and human activities along the coastal strip, in conjunction with increasing urbanisation, results in growing human pressure on the coastal system leading to the disruption of the equilibrium processes. 
Areas in close proximity to these facilities are considered more vulnerable. The assumption was made that only sandy areas were impacted by the proximity to infrastructural developments. Figure 4 shows the anthropogenic activities in the area. For the ports, a buffer zone was created for each port (with varying radii based on the relative size of the port as shown in Table 3). A point on the coastline was assigned a vulnerability value of 5 if it fell in both the sandy zone and the port's buffer zone. The rest of the points were assigned a value of zero.

Table 3. A list of ports, their relative sizes and the estimated buffer zone size used

\begin{tabular}{llllll}
\hline Harbour & Relative size & Buffer zone & Harbour & Relative size & Buffer zone \\
Lambert's Bay & Very small & $800 \mathrm{~m}$ & East London & Medium & $3 \mathrm{~km}$ \\
Struisbaai & Very small & $400 \mathrm{~m}$ & Cape Town & Large & $2.2 \mathrm{~km}$ \\
Vleesbaai & Very small & $1.5 \mathrm{~km}$ & Port Elizabeth & Large & $10 \mathrm{~km}$ \\
Gordon's bay & Small & $400 \mathrm{~m}$ & Richards Bay & Large & $5 \mathrm{~km}$ \\
Hout Bay & Small & $1.4 \mathrm{~km}$ & Simons Town & Large & $1.7 \mathrm{~km}$ \\
Mossel Bay & Small & $1 \mathrm{~km}$ & Ngqura (Coega) & Very Large & $16 \mathrm{~km}$ \\
Saldanha & Medium & $8 \mathrm{~km}$ & Durban & Very large & $14 \mathrm{~km}$ \\
\hline
\end{tabular}

In the case of breakwaters, a 100m buffer was created and when it intersected with an adjacent sandy beach a vulnerability value of 3 was assigned to points falling on the sandy beach and the breakwater buffer. The presence of dams inland of river mouths was considered significant in that this may assist the reduction of sediment input into the coastal area.

A $1 \mathrm{~km}$ buffer was created around the mouths of perennial rivers on the coast containing dams within their catchments. In the case of river mouths bordered by sandy beaches, the vulnerability value of 4 was assigned. The rest of the points were assigned a value of zero.

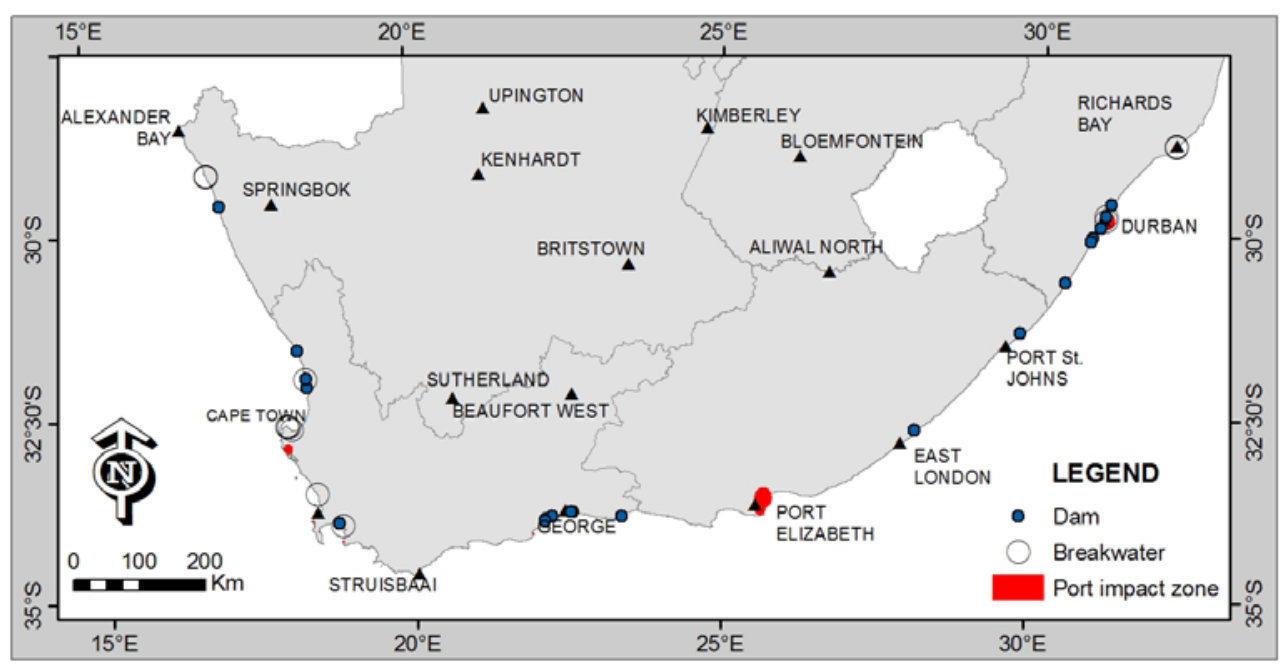

Figure 4. The anthropogenic activities used in the study 


\subsection{Distance to $20 \mathrm{~m}$ isobaths}

In terms of coastal vulnerability, the greater the distance from the shoreline to the $20 \mathrm{~m}$ isobaths (defined at the contour beyond which sea depth is $>20 \mathrm{~m}$ ), the greater the dissipation of wave energy. Subsequently, a reduction in wave energy reaching the shoreline entails lower vulnerability to the effects of extreme weather conditions (Davies, 2012). The distance between the 20m isobath and the coastline was estimated and a vulnerability index was assigned to vector points as highlighted in Table 1 . Figure 5 shows the $20 \mathrm{~m}$ isobaths and the distances from the coastline around the Western Cape Province.

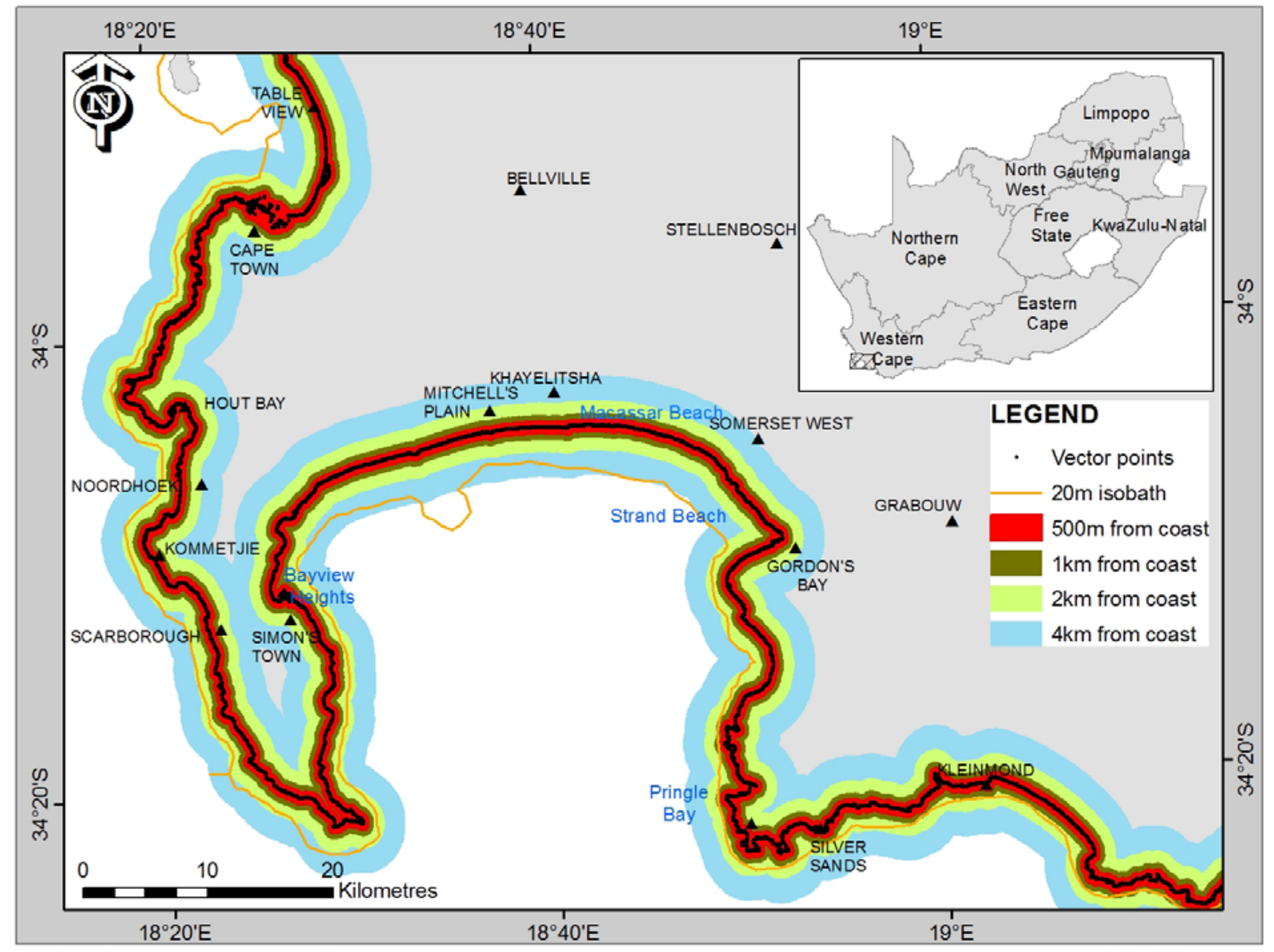

Figure 5. Distances to the coast and the $20 \mathrm{~m}$ isobath for the Western Cape area

\subsection{Relative sea-level change}

Relative sea level change (mm/year) corresponds to how the global (eustatic) sea-level rise and local tectonic processes (land motion such as uplift or subsidence) have affected a section of shoreline. Relative sea-level change coastal vulnerability classes utilised were based on the United States Geological Survey (USGS) coastal vulnerability index study undertaken for the US Atlantic margin (Thieler and Hammar-Klose, 1999). 
The values used were obtained from Mather et al., 2009 and are shown in Table 4.

Table 4. A list of stations and the relative sea-level rise

\begin{tabular}{lll}
\hline Region & Station & Sea level change (mm.y-1) \\
Western coast & Port Nolloth/Alexander Bay & +0.42 \\
South coast & Simon's Town/Cape Town & +1.48 \\
& Granger Bay/ Cape Town & +0.78 \\
& Mossel Bay/George & -0.15 \\
& Knysna/George & +2.45 \\
East Coast & Port Elizabeth & +3.49 \\
Saldanha & Durban & +3.61 \\
\hline
\end{tabular}

A $10 \mathrm{~km}$ buffer was created around the stations and each vector point within the buffer was assigned the same vulnerability class as the station around which the buffer was created. A point outside a buffer was allocated a value average of the two nearest stations.

\section{Results and discussion}

The coastal vulnerability map was created by adding the equally weighted parameters together using map algebra (spatial overlay) in the ArcGIS software using the Spatial Analysis extension. The resulting map is shown in Figure 6 and the raster has a spatial resolution of $150 \times 150$ metres. The coastal vulnerability index for the South African coastline shows expected variability in the indices, in accordance with geological substrate, elevation of the coastal plain and the presence of infrastructure. We propose that geological substrate is the most significant contributor to the vulnerability index, as the erodibility of lithologies will likely govern the resultant gradient of the coastal plain (Roberts et al., 2013; Cawthra et al., 2014). The results for various sections of the coast are discussed in detail in the following sections. 


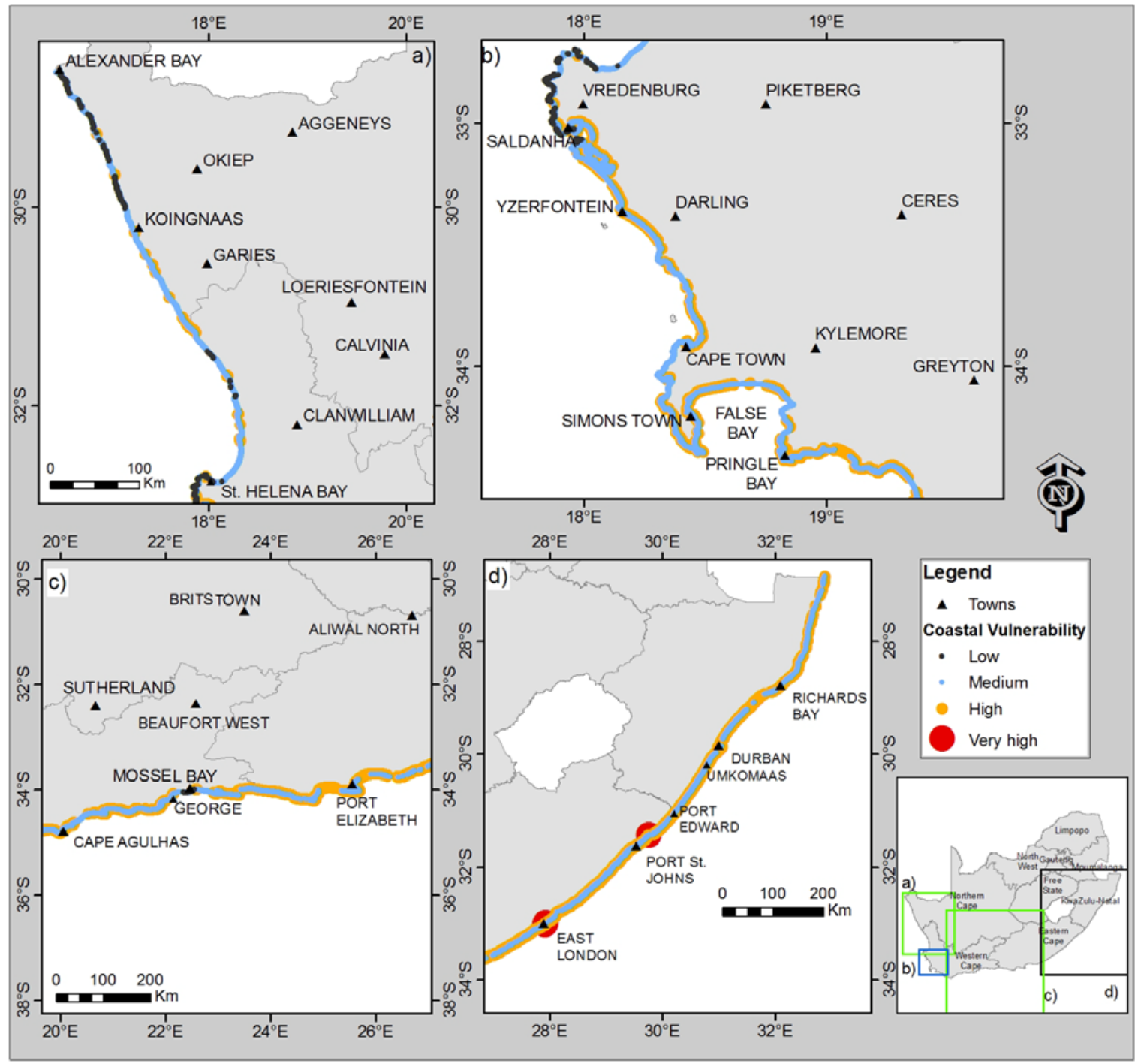

Figure 6. The regional coastal vulnerability index for the South African coastline based on a combination of parameters described in Table 1

\subsection{The west coast}

The results show that the vulnerability is generally lowest on the northwest coast, south of the Orange River where the metamorphic rocks of the Stinkfontein Group crop out at the coast. The vulnerability increases to medium values through St Helena Bay which is generally characterised by mixed rocky and sandy beaches with low coastal gradients. Near the southern extent of St Helena Bay where Cape Granites are exposed at the coast, the vulnerability index indicates that the region between Saldanha Bay and St Helena Bay is relatively resistant to coastal erosion, where the values were grouped in the low range. Towards the region surrounding the City of Cape Town, the variable range in values is interpreted to reflect the variation in coastal geology and the anthropogenic infrastructure. 
These values range from medium to high, the latter being associated with the sandy beaches of Table Bay and False Bay. Where the high values are prevalent, this is generally a function of the location of ports and associated infrastructure (Figures 6a and 6b).

\subsection{The south coast}

The continuity of the southern Cape coast from Port Elizabeth in the east to Cape Agulhas in the west is broken by a series of zeta bays. These are linked to deformation associated with the Gondwana break-up (Watkeys, 2006) and the formation of several half-grabens (for example Mossel Bay and Algoa Bay). The bedrock lithology of pre-Cenozoic strata along the south coast is highly variable, creating variations in geomorphic expression (Roberts et al., 2013). Resistant lithologies bounding the south coast log-spiral embayments tend to form rocky headlands of steep sea cliffs which inhibit the development of sandy beaches and hence, coastal dune systems. This geological signature is closely mirrored in the coastal vulnerability index, which ranges intermittently between the medium and high ranges (Figure 6c).

\subsection{The east coast}

The east coast of South Africa is narrow compared to the global average of $78 \mathrm{~km}$ (Kennett, 1982) ranging between $4 \mathrm{~km}$ and $20 \mathrm{~km}$ in width. The presence of steep, competent Msikaba Formation lithologies along the shoreline from East London to Port Edward separate locally developed sandy embayments and are significantly dissected by rivers (Fisher et al., 2013). Although the resistant lithologies exhibit a medium index on the river mouths, the narrow shelf and steep shoreline account for the scattered very high indices.

The KwaZulu-Natal south coast, extending from Port Edward to Umkomaas, is characterised by outcrops of the Natal Metamorphic Province. These vulnerability index values predominantly fall within the medium range. North of Durban, vast sandy beaches dominate the coast as a function of a broad coastal plain underlain by erodible Cretaceous strata of the Thekwini and Zululand Basins (after Broad et al., 2006). These stretches of coast are generally classified as highly vulnerable. For regions in central kwaZulu-Natal, however, with Karoo Supergroup deposits outcropping at the shoreline, the vulnerability index suggests a decrease in susceptibility to erosion to medium values. 


\section{Conclusions and recommendations}

The effects of sea-level rise include increases in the coastal processes of erosion. In this study GIS-based techniques were used to classify potential erosion in the assignment of a vulnerability index. This index considers parameters including geological substrate, elevation and exposure to wave attack, which have been shown in previous studies to be strongly influential. We propose that geological substrate is the most significant contributor to the vulnerability index, as the erodibility of lithologies will likely govern the resultant gradient of the coastal plain.

The methodology explored is suitable for regional studies because the datasets for this scale of analysis are readily available. The method is applicable for any area in the world because the datasets used are universal. The results are used as a first pass in identifying hotspots for more detailed site specific studies. Temporal analyses are not viable on a regional scale but on more sitespecific local studies this is possible and can be done seasonally. Some of the parameters that can be temporally monitored include the beach width, wave height and athropogenic activities. Some beaches in South Africa, for example in the city of Durban, are already being monitored (Palmer et al., 2010).

The assessment criteria for the study have some known limitations. Several generalisations have been made on some of the parameters used, which include the buffer sizes used to assign vulnerability to adjacent areas, beach width measurements and distances to $20 \mathrm{~m}$ isobath. To overcome these limitations more detailed input data sets will be required. The cost involved will not necessarily result in big differences in results. The other limitation arises from the choice of the distance between vector points, ranging between 30-100 metres. This resolution is course and vulnerable areas within this range will likely be missed. However, this is more problematic at detailed scales and on a regional scale this is sufficient given the resolution of the data used and it is comparable to other studies. Another aspect that might affect the results is the equal weighting of the parameters. The parameters could be weighted on their significance to coastal vulnerability and this can be done in an objective approach using expert knowledge and techniques like the analytic hierarchy process (AHP) (Duriyapong and Nakhapakorn, 2011).

Future research can involve the inclusion of more parameters for example shoreline erosion/accretion rates, groundwater parameters and socio-economic aspects for example the number of people affected, infrastructure potentially damaged and economic costs (Ramieri et al., 2011). More sophisticated computer tools, for example DESYCO and InVEST can be used to assess coastal vulnerability although their use is limited by the lack of the required detailed data. When computer models are used, automation is possible as it enables the rapid change in parameter values when more data is collected and this will enable the time-series monitoring of coastal vulnerability. 


\section{Acknowledgements}

The authors would like to acknowledge the Department of Science and Technology (DST) for funding this project. We would like to thank the Council for Geoscience for the resources and the time given to conduct this work. Dr Kerry Sink (SANBI) is acknowledged for providing the beach classification data.

\section{References}

Broad, DS, Jungslager, EHA, McLachlan, IR, \& Roux, J 2006, ‘Offshore Mesozoic Basins,' in MR Johnson, CR Annhauser and RJ Thomas (eds.), The Geology of South Africa, Geological Society of South Africa, Johannesburg/Council for Geoscience, Pretoria, pp.553-571.

Bryan, B, Harvey, N, Belperio, T \& Bourman, B 2001, 'Distributed process modeling for regional assessment of coastal vulnerability to sea-level rise', Environmental Modeling and Assessment, vol. 6, pp. 57-61.

Cawthra, HC, Bateman, MD, Carr, AS, Compton, JS \& Holmes, PJ 2014, 'Understanding Late Quaternary change at the land-ocean interface: a synthesis of the evolution of the Wilderness coastline, South Africa', Quaternary Science Reviews, vol. 99, pp. 210-223.

Cooper, JAG 2001, 'Geomorphological variability among microtidal estuaries from the wavedominated South African coast', Geomorphology, vol. 40, pp. 99-122.

Davies, JL 1980, Geographical variation in coastal development, Longman, New York, pp. 212.

Davies, WTR 2012, ‘Applying a Coastal Vulnerability Index (CVI) to the Westfjords, Iceland: a preliminary assessment', MSc Thesis, University of Akureyi, viewed March 2014, <http://skemman.is/stream/get/1946/12297/29993/1/William_Davies_-

_Applying_a_Coastal_Vulnerability_Index_\$0028CVI\$0029_to_the_Westfjords_Iceland_a_pre liminary_assessment___REVISED___FORMATTED.pdf $>$.

Doukakis, E 2005, ‘Coastal Vulnerability and Risk Parameters', European Water, vol. 11/12, pp. 37.

Duriyapong, F, \& Nakhapakorn, K 2011, 'Coastal vulnerability assessment: a case study of SamutSakhon coastal zone', Journal of Science and Technology, vol. 33, no. 4, pp. 469-476.

Fisher, EC, Albert, RM, Botha, GA, Cawthra, HC, Esteban, I, Harris, J, Jacobs, Z, Jerardino, A, Marean, CW, Neumann, FH, Pargeter, J, Poupart, M \& Venter, J 2013, ‘Archaeological Reconnaissance for Middle Stone Age Sites along the Pondoland Coast, South Africa', Palaeoanthropology, pp. 104-137.

Harris, L, Nel, R, \& Schoeman, D 2011, 'Mapping beach morphodynamics remotely: A novel application tested on South African sandy shores', Estuarine Coastal and Shelf Science, vol. 92, pp. 78-89. 
IPCC 2007, 'Climate change 2007: the scientific basis,' Cambridge University Press, Cambridge

Kennett, JP 1982, Marine Geology, Prentice-Hall, London.

Mather, AA, Garland, GG \& Stretch, DD 2009, 'Southern African sea levels: corrections’, influences and trends', African Journal of Marine Science, vol. 31, no. 2, pp. 145-156.

Mukheibir, P, \& Ziervogel, G 2007, 'Developing a Municipal Adaptation Plan (MAP) for climate change: the city of Cape Town', Environment and Urbanization, vol. 19, no.1, pp. 143-158.

Palmer, BJ, Van der Elst, R, Mackay, F, Mather, AA, Smith, AM., Bundy, SC, Thackeray, Z, Leuci, R \& Parak, O 2011, 'Preliminary coastal vulnerability assessment for KwaZulu-Natal, South Africa', Journal of Coastal Research, Special Issue 64 (ICS2011 Proceedings),vol. 64, pp. 1390-1395.

Ramieri, E, Hartley, A, Barbanti, A, Duarte Santo, F, Gomes, A, Hilden, M, Laihonen, P, Marinova, N \& Santini, M 2011, 'Methods for assessing coastal vulnerability to climate change', ETC CCA Technical Paper 1/2011, European Environment Agency, viewed December 2014, < http://cca.eionet.europa.eu/docs/TP_1-2011>.

Roberts, DL, Cawthra, HC \& Musekiwa, C 2013, 'Dynamics of late Cenozoic aeolian deposition along the South African coast: A record of evolving climate and ecosystems’, in: Martini, IP, Wanless, HR (eds.) Sedimentary Coastal Zones from High to Low Latitudes: Similarities and Differences, Geological Society, London, Special Publications, vol. 388, pp. 353-387.

Roberts, D 2010, 'Prioritizing climate change adaptation and local level resilience in Durban, South Africa', Environment and Urbanization, vol. 22, no.2, pp. 397-413.

Sharp, R, Chaplim-Kramer, R, Wood, S, Guerry, A, Tallis, H \& Ricketts, T 2010, 'InVEST User’s Guide: Integrated Valuation of Environmental Services and Tradeoffs', viewed November 2014, $<$ http://ncp-dev.stanford.edu/ dataportal/invest releases/documentation/current_release/index.html\#>.

Thieler, ER \& Hammar-Klose, ES 1999, 'National Assessment of Coastal Vulnerability to SeaLevel Rise: Preliminary Results for the U.S. Atlantic Coast', U.S. Geological Survey Open-File Report 99-593, viewed December 2010, <http://pubs.usgs.gov/of/1999/of99-593/index.html>.

United States Geological Survey (USGS) 2001, 'Vulnerability of US National Parks to Sea-Level Rise and Coastal Change', viewed December 2014, < http://pubs.usgs.gov/fs/fs095-02/fs09502.pdf $>$.

Watkeys, MK 2006, 'Gondwana break-up: A South African perspective', in MR Johnson, CR Annhauser and RJ Thomas (eds.), The Geology of South Africa, Geological Society of South Africa, Johannesburg/Council for Geoscience, Pretoria, pp. 531-539.

Windguru, 2014. Viewed January 2014, http://www.windguru.cz/int/?sc=91. 